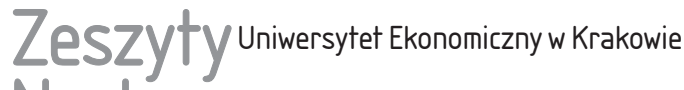 Naukowe
}

\section{Wpływ odroczonego podatku dochodowego na kształtowanie wyniku finansowego jednostki gospodarczej}

\section{Streszczenie}

Celem artykułu jest wskazanie rozbieżności między prawem bilansowym i podatkowym w zakresie ustalania wyniku finansowego (dochodu podatkowego) oraz przedstawienie roli odroczonego podatku dochodowego w kompensowaniu obciążeń podatkowych, tak aby były zgodne z nadrzędnymi zasadami rachunkowości. W artykule zastosowano metodę analizy rachunków zysków i strat opublikowanych przez dwa podmioty losowo wybrane z listy największych przedsiębiorstw w Polsce w 2016 r. Zbadano relacje, jakie pojawiłyby się, gdyby podmiot ustalał i nie ustalał odroczonego podatku dochodowego, a także jak kształtowałby się wskaźnik zysku w obu sytuacjach. Na podstawie tak przeprowadzonej analizy sformułowano wstępny wniosek o istotnym wpływie odroczonego podatku dochodowego na kształtowanie się zysku netto. Wniosek ten wymagać będzie jednak zweryfikowania na dużo większej próbie badawczej.

Słowa kluczowe: odroczony podatek dochodowy, metoda zobowiązań bilansowych, sprawozdawczość finansowa, rentowność.

Klasyfikacja JEL: M41.

Krzysztof Jonas, Uniwersytet Ekonomiczny w Krakowie, Wydział Finansów i Prawa, Katedra Rachunkowości Finansowej, ul. Rakowicka 27,31-510 Kraków, e-mail: jonask@uek.krakow.pl 


\section{Wprowadzenie}

W istniejącym w Polsce systemie prawnym można wyróżnić dwa podejścia służące temu samemu celowi, tj. ustaleniu rezultatów działalności jednostki gospodarczej - są to prawo bilansowe i prawo podatkowe. Jednostka, stosując prawo bilansowe, ustala wynik finansowy będący, w dużym skrócie, różnicą między przychodami i kosztami z różnych segmentów działalności. Stosując prawo podatkowe, ustala dochód (lub stratę) będący różnicą między przychodami w rozumieniu podatkowym a kosztami uzyskania przychodu. Pomiar wyniku finansowego w systemie prawa bilansowego musi uwzględniać również podatek dochodowy, którego wielkość ustalana jest poza tym systemem. Obciążenie podatkowe wyniku finansowego nie może być jednak tożsame z płatnościami podatkowymi, gdyż wynik finansowy musi być obciążony współmierną kwotą podatku dochodowego (Walińska 1997, s. 127). Dodatkowo, nie wszystkie kategorie przychodów i kosztów są w jednakowy sposób uznawane przez prawo podatkowe. Można uznać za normę sytuację, gdy wynik finansowy jest różny od dochodu. Dlatego też pojawiła się koncepcja odroczonego podatku dochodowego, którego głównym zadaniem jest skorygowanie wysokości podatku dochodowego ustalonego zgodnie z przepisami podatkowymi, tak aby wysokość obciążenia podatkowego była zgodna z nadrzędnymi zasadami rachunkowości. Koncepcja ta ma za zadanie uniezależnić prawo bilansowe od przepisów prawa podatkowego, tak aby można przeprowadzić całą procedurę ustalania wyniku finansowego zgodnie z nadrzędnymi zasadami rachunkowości. Warto przy tym zwrócić uwagę, że pomimo swej nazwy odroczony podatek dochodowy jest kategorią istniejącą wyłącznie w rachunkowości.

Głównym celem artykułu jest ukazanie wpływu odroczonego podatku dochodowego na wysokość zysku netto w jednostkach gospodarczych. Celem pośrednim jest zwrócenie uwagi na wpływ podatku odroczonego na wartość wskaźników stosowanych w analizie finansowej ${ }^{1}$. Do realizacji tak określonego celu zastosowano metodę przeglądu aktów prawnych oraz obowiązujących krajowych i międzynarodowych standardów w celu przedstawienia zasad ustalania i rozliczania odroczonego podatku dochodowego. Wykorzystano również analizę krajowej i zagranicznej literatury przedmiotu. Dokonano także analizy sprawozdań finansowych wybranych jednostek gospodarczych w celu zidentyfikowania badanego problemu.

${ }^{1}$ Szczególnie ważne, biorąc pod uwagę podatek odroczony, są badania rentowności przedsiębiorstw, zob. np. badania prowadzone przez T. Maślankę (2014, s. 223-256). 


\section{Odroczony podatek dochodowy w ewidencji ksiegowej i sprawozdawczości finansowej}

Podstawę prawną funkcjonowania odroczonego podatku dochodowego stanowi ustawa o rachunkowości (Ustawa z dnia 29 września 1994 r. ...) wraz z aktami wykonawczymi. Dodatkowo wykorzystuje się Krajowy standard rachunkowości nr 2 „Podatek dochodowy” (KSR 2), a także Międzynarodowy standard rachunkowości nr 12 (MSR 12) o takiej samej jak KSR nazwie. Co do ogólnej zasady, to każda jednostka gospodarcza, która podlega ustawie o rachunkowości, ma obowiązek ustalać odroczony podatek dochodowy. Istnieje jednak pewien przywilej umożliwiający niektórym jednostkom rezygnację z tego obowiązku. W art. 37 ust. 10 ustawy o rachunkowości określono, że jednostki, które ze względu na rozmiary swojej działalności mogą zostać uznane za jednostki mikro i jednostki małe, mogą również zrezygnować $z$ ustalania i rozliczania odroczonego podatku dochodowego. Przepis ten został wprowadzony nowelizacją ustawy o rachunkowości w 2015 r. (Ustawa z dnia 23 lipca 2015 r....), która weszła w życie od 2016 r. Poprzednio przywilej ten dotyczył tych jednostek, które ze względu na swoje rozmiary nie podlegały badaniu przez biegłego rewidenta. Takie uregulowanie oznacza, że mniejsze jednostki mogą posługiwać się jedynie podatkiem dochodowym w sensie fiskalnym (bez korekty o podatek odroczony), co zdecydowanie ułatwia ustalenie wyniku finansowego netto. Przywilej ten - zgodnie z ust. 11 wspomnianego wcześniej artykułu - nie ma jednak zastosowania do niektórych jednostek, które ustawodawca uznał za szczególnie ważne gospodarczo, jak np. banki czy zakłady ubezpieczeń.

Jednostka, która podejmuje decyzję o rezygnacji z ustalania odroczonego podatku dochodowego, ma obowiązek zaznaczyć ten fakt we wprowadzeniu do sprawozdania finansowego. W ramach polityki rachunkowości jednostka powinna zamieścić informację, że rezygnuje z ustalania odroczonego podatku dochodowego. Zamieszczenie takiej informacji jest bardzo ważne, gdyż oznacza to, że w rachunku zysków i strat podatek dochodowy jest wyłącznie podatkiem bieżącym w rozumieniu przepisów podatkowych, a w bilansie nie ma aktywów i rezerw z tytułu odroczonego podatku dochodowego.

Obecnie obowiązująca metoda zobowiązań bilansowych została wprowadzona wraz z nowelizacją ustawy o rachunkowości z 2000 r. (Ustawa z dnia 9 listopada 2000 r. ...). Metoda ta opiera się na różnicach pomiędzy wartościami bilansowymi i podatkowymi aktywów i pasywów. Różnice polegające na uznawaniu danego składnika aktywów czy pasywów w różnych okresach określa się jako przejściowe. Natomiast różnice polegające na definitywnym nieuznawaniu danej kategorii przez prawo bilansowe lub podatkowe określa się jako różnicę trwałą niepowodującą powstawania odroczonego podatku dochodowego. Biorąc pod 
uwagę podatek odroczony, istotne są więc jedynie różnice przejściowe, które powstają, jeśli wartość bilansowa jest różna od wartości podatkowej².

Wartość bilansowa nie jest określona wprost w ustawie o rachunkowości, z zapisów ustawowych można jednak wywnioskować, że jest to wartość, według której dany składnik został wykazany w księgach rachunkowych i w sprawozdaniu zgodnie z obowiązującymi zasadami wyceny. Podobnie wartość bilansowa jest zdefiniowana w KSR 2. Wartość podatkowa natomiast jest ustalania zgodnie z postrzeganiem danej kategorii przez przepisy podatkowe, przy czym inaczej jest postrzegana wartość podatkowa aktywów, a inaczej pasywów.

Wartość podatkowa aktywów została określona w art. 37 ust. 2 ustawy o rachunkowości jako kwota wpływająca na pomniejszenie podstawy obliczenia podatku dochodowego w przypadku uzyskania z nich w sposób bezpośredni lub pośredni korzyści ekonomicznych. Jeżeli uzyskanie korzyści ekonomicznych z danych aktywów nie będzie powodowało pomniejszenia podstawy obliczenia podatku dochodowego (korzyści nie są opodatkowane), wówczas wartość podatkowa będzie równa wartości księgowej. W literaturze przedmiotu powszechnie funkcjonuje uproszczenie (Olchowicz 2009), że wartość podatkowa aktywów to przyszły koszt uzyskania przychodu.

Wartość podatkowa pasywów określona została w art. 37 ust. 3 ustawy o rachunkowości jako wartość księgowa pomniejszona o kwoty, które w przyszłości pomniejszą podstawę podatku dochodowego. Dodatkowo w MSR 12 omówiona została sytuacja - nieuwzględniona w ustawie o rachunkowości otrzymania przychodów z wyprzedzeniem (np. czynsz otrzymany z góry za rok), a więc powstania przychodów przyszłych okresów; wskazano, że wartość podatkowa takich pasywów to wartość księgowa pomniejszona o kwoty przychodów niepodlegających opodatkowaniu w przyszłości (opodatkowaniu podlega cała kwota w momencie jej otrzymania). Dlatego też w przypadku wartości podatkowej pasywów funkcjonują dwa uproszczenia (Olchowicz 2009) - że jest ona równa, po pierwsze, wartości księgowej pomniejszonej o koszt uzyskania przychodu oraz, po drugie, wartości księgowej pomniejszonej o wartość przychodów niepodlegających opodatkowaniu w przyszłości.

Ustalenie wartości bilansowej i wartości podatkowej aktywów i pasywów pozwala na zidentyfikowanie wartości różnic, jakie mogą wystąpić. W przypadku aktywów, jeżeli wartość bilansowa jest większa od wartości podatkowej, różnicę określa się jako dodatnią. Jeśli natomiast wartość bilansowa jest mniejsza od wartości podatkowej, różnicę określa się jako ujemną.

W przypadku pasywów interpretacja jest odwrotna, tzn. jeżeli wartość bilansowa jest większa od wartości podatkowej, różnicę określa się jako ujemną,

${ }^{2}$ Metodę zobowiązań bilansowych szerzej omawiają m.in. E. Walińska (2003), I. Olchowicz (2009), A. Hołda (2013) oraz I. Olchowicz i A. Tłaczała (2008). 
natomiast jeżeli wartość bilansowa jest mniejsza od wartości podatkowej, różnicę określa się jako dodatnią. Przykłady powstawania różnic przejściowych dodatnich i ujemnych podano w tabelach 1 i 2 .

Tabela 1. Przykłady powstawania różnic przejściowych dodatnich

\begin{tabular}{|l|}
\hline \multicolumn{1}{|c|}{ Różnice przejściowe dodatnie } \\
\hline $\begin{array}{l}\text { Srodki trwałe i wartości niematerialne i prawne amortyzowane bilansowo wolniej (niższe } \\
\text { stawki) niż podatkowo }\end{array}$ \\
$\begin{array}{l}\text { Przyjęcie do użytkowania środków trwałych o niskiej jednostkowej wartości amortyzowanych } \\
\text { podatkowo jednorazowo, a księgowo liniowo }\end{array}$ \\
Zarachowanie w ramach wyceny niezrealizowanych dodatnich różnic kursowych \\
\hline Zwiększenie wyceny do wartości godziwej lub innej \\
\hline Naliczone i nieotrzymane odsetki od pożyczek \\
\hline $\begin{array}{l}\text { Zarachowanie niezrealizowanych dodatnich różnic kursowych dotyczących wyceny bilansowej } \\
\text { należności }\end{array}$ \\
\hline Memoriałowe naliczenie odsetek za zwłokę \\
\hline $\begin{array}{l}\text { Zwiększenie ceny nabycia towarów lub kosztu wytworzenia produktów o koszty obsługi } \\
\text { zobowiązań }\end{array}$ \\
\hline Koszty remontów rozliczanych w czasie, podatkowo rozliczone w momencie poniesienia \\
\hline $\begin{array}{l}\text { Koszty zapłaconych za kilka okresów sprawozdawczych czynszów, składek na ubezpieczenia } \\
\text { majątkowe, wydatków dotyczących działalności podstawowej, podatkowo rozliczone w momencie } \\
\text { zapłaty }\end{array}$ \\
\hline $\begin{array}{l}\text { Zapłacone z góry odsetki, prowizje od zaciągniętych kredytów aktywowane księgowo, a zali- } \\
\text { czone do kosztów podatkowych z tytułu zapłaty }\end{array}$ \\
\hline $\begin{array}{l}\text { Zarachowanie niezrealizowanych dodatnich różnic kursowych dotyczących wyceny bilansowej } \\
\text { zobowiązań }\end{array}$ \\
\hline
\end{tabular}

Źródło: opracowanie własne na podstawie (Rachunkowość... 2005, s. 498-518).

Określenie dodatnich i ujemnych różnic przejściowych pozwala na ustalenie aktywów i rezerw z tytułu odroczonego podatku dochodowego. Zgodnie z art. 37 ust. 5 ustawy o rachunkowości rezerwę z tytułu odroczonego podatku dochodowego tworzy się w wysokości kwoty podatku dochodowego przypadającej w przyszłości do zapłaty w związku z wystąpieniem dodatnich różnic przejściowych, czyli różnic, które spowodują zwiększenie podstawy obliczenia podatku dochodowego w przyszłości. Dlatego też wartość rezerwy z tego tytułu tworzy się, mnożąc wartość różnicy dodatniej przez obowiązującą stawkę podatkową. Aktywa z tytułu odroczonego podatku dochodowego (art. 37 ust. 4) ustala się w wysokości kwoty przewidzianej do odliczenia od podatku dochodowego w związku z ujemnymi różnicami przejściowymi, które spowodują w przyszłości zmniejszenie podstawy 
obliczenia podatku dochodowego. Wartość aktywu z tego tytułu tworzy się, mnożąc wartość różnic ujemnych przez obowiązującą stawkę podatkową.

Tabela 2. Przykłady różnic przejściowych ujemnych

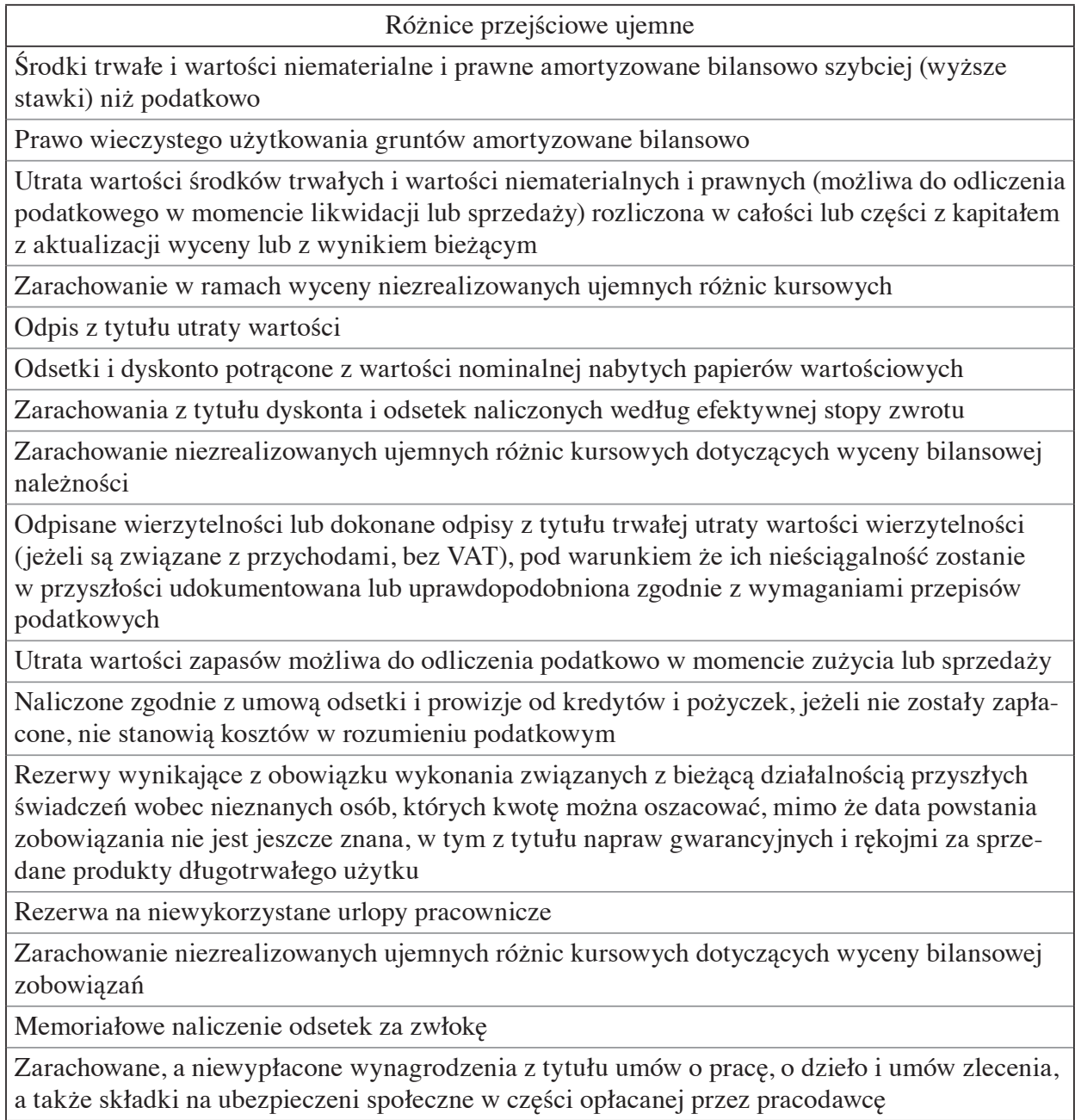

Źródło: opracowanie własne na podstawie (Rachunkowość... 2005, s. 498-518).

Warto w tym miejscu wspomnieć o jeszcze jednym sposobie powstawania aktywów z tytułu podatku odroczonego, a mianowicie o stracie podatkowej możliwej do odliczenia w przyszłości (Olchowicz 2009, s. 320-324). Jest to ciekawa sytuacja, ponieważ przepisy prawa bilansowego korzystają tu wprost z uregulowań pochodzących z prawa podatkowego. Po pierwsze, strata musi być 
ustalona zgodnie z przepisami podatkowymi, a więc przychody w rozumieniu podatkowym minus koszty uzyskania przychodu. Po drugie, strata musi być możliwa do odliczenia, a zatem jednostka musi sama określić, czy w następnych latach osiągnie dochody pozwalające jej na odliczenie tej straty (przy odliczaniu kieruje się przepisami podatkowymi). Według obecnych rozwiązań ma na to 5 kolejno po sobie następujących lat podatkowych, rocznie ma prawo odliczyć maksymalnie 50\% wartości straty oraz musi posiadać dochód pozwalający jej na odliczenie straty (Ustawa z dnia 26 lipca 1991 r...., Ustawa z dnia 15 lutego 1992 r. ...). W ustawie o rachunkowości (art. 37 ust. 4) podkreśla się zachowanie zasady ostrożności przy ustalaniu wartości aktywów z tytułu odroczonego podatku dochodowego. Oznacza to, że jeśli jednostka orzeknie, że nie będzie w stanie odliczyć całej straty, tylko jej część (np. 70\%), to może utworzyć aktywa od tej części, którą będzie w stanie odliczyć. Po utworzeniu aktywów z tytułu odroczonego podatku dochodowego w miarę jak jednostka będzie rozliczać stratę podatkowo, w takim samym tempie będzie rozwiązywać aktywa utworzone od tej straty. Jeśli po upływie określonego przepisami okresu (obecnie 5 lat) jakaś część straty nie zostanie rozliczona podatkowo, wówczas ta kwota przepada. Natomiast odpowiadająca tej kwocie część aktywów z tytułu podatku odroczonego zostaje po upływie tego okresu dodatkowym zapisem wyksięgowana (nie przepada).

Wartość odroczonego podatku dochodowego ustala się i rozlicza z taką samą częstotliwością, z jaką jednostka sporządza sprawozdania finansowe. Jeśli więc jednostka sporządza jedynie sprawozdanie finansowe na koniec roku, wówczas podatek odroczony obliczany jest na ten dzień. Wartość podatku odroczonego może ulec zmianie na skutek (Rachunkowość... 2005, s. 494):

- zmiany wartości różnic przejściowych,

- zmiany stawek podatkowych lub przepisów podatkowych (np. w zakresie rozliczania strat),

- korekty możliwości realizacji aktywów z tytułu odroczonego podatku dochodowego,

- zmiany przewidywanego sposobu realizacji wartości składnika aktywów trwałych.

W przypadku sprawozdawczości finansowej istotne znaczenie ma nie tylko wartość końcowa rezerwy i aktywu z tytułu odroczonego podatku dochodowego umieszczana w bilansie, ale również zmiana stanu tych kategorii (różnica między stanem końcowym a początkowym), która wpływa na obciążenie podatkowe umieszczana w rachunku zysków i strat. Wyjątkiem są tu rezerwy i aktywa z tytułu podatku odroczonego dotyczące operacji rozliczanych z kapitałem własnym jednostki. Wówczas zmiana stanu aktywów i rezerwy z tytułu podatku dochodowego odnoszona jest również na kapitał własny. 
Zgodnie z art. 37 ust. 8 ustawy o rachunkowości na wynik finansowy wpływa podatek dochodowy składający się z części bieżącej (jest to podatek należny do zapłaty za dany okres) oraz części odroczonej (jest to zmiana stanu aktywów i rezerwy z tytułu podatku odroczonego). Wpływ zmiany stanu rezerwy z tytułu odroczonego podatku dochodowego na obciążenie podatkowe jest wprost proporcjonalny, tzn. jeżeli wartość rezerwy rośnie, obciążenie wyniku finansowego podatkiem dochodowym również rośnie, a jeśli wartość rezerwy maleje, obciążenie wyniku finansowego podatkiem dochodowym również maleje. Natomiast wpływ zmiany stanu aktywów z tytułu odroczonego podatku dochodowego jest odwrotnie proporcjonalny, tzn. gdy wartość aktywów rośnie, obciążenie wyniku finansowego podatkiem dochodowym maleje, a jeśli wartość aktywów spada, obciążenie wyniku finansowego podatkiem dochodowym rośnie. Sposób oddziaływania tych kategorii na obciążenie podatkowe wynika wprost z zasady podwójnego zapisu. Zaewidencjonowanie zmian stanu pozwala na skorygowanie wartości podatku należnego (część bieżąca podatku w sprawozdaniu) do wartości obciążenia podatkowego zgodnego z nadrzędnymi zasadami rachunkowości. Odroczony podatek może więc odgrywać istotną rolę w ustaleniu wartości zysku netto. Jeśli część odroczona będzie powiększać obciążenie podatkowe, zysk netto będzie mniejszy, jeżeli pomniejszy obciążenie, zysk netto wzrośnie. Jeśli te korekty będą istotne, może mieć to znaczenie przy ocenie sytuacji finansowej i majątkowej jednostki gospodarczej.

Odroczony podatek dochodowy pojawia się we wszystkich sprawozdaniach sporządzanych przez jednostkę, lecz jego rola w nich jest bardzo różna.

W informacji dodatkowej podatek odroczony pojawia się dwukrotnie:

1) we wstępie do sprawozdań finansowych (o czym wspominano już wcześniej), oraz

2) w dodatkowych informacjach i objaśnieniach:

- w ramach punktu 1.8 „Dane o stanie rezerw według celu ich utworzenia na początek roku obrotowego, zwiększeniach, wykorzystaniu, rozwiązaniu i stanie końcowym" jednostka podaje informacje na temat zmian stanu rezerwy z tytułu odroczonego podatku dochodowego,

- w ramach punktu 1.11 „Wykaz istotnych czynnych i biernych rozliczeń międzyokresowych" jednostka podaje informacje na temat aktywów z tytułu odroczonego podatku dochodowego.

Informacja dodatkowa jest więc odpowiednim miejscem do szukania szczegółowych informacji na temat tego, co się zdarzyło w ciągu roku obrotowego w ramach rozliczenia podatku odroczonego.

W bilansie aktywa $\mathrm{z}$ tytułu odroczonego podatku dochodowego prezentuje się w ramach aktywów trwałych jako element kategorii „długoterminowe rozliczenia międzyokresowe". Zaliczenie aktywów z tytułu odroczonego podatku dochodo- 
wego do tej kategorii następuje bez względu na okres rozliczenia aktywów zgodnie z MSR 12, w którym nie uzasadnono takiej klasyfikacji. Rezerwę z tytułu odroczonego podatku dochodowego prezentuje się w pasywach jako element grupy B „Zobowiązania i rezerwy na zobowiązania” w ramach rezerw na zobowiązania. Bilans jest więc jedynym miejscem w sprawozdawczości finansowej, w którym widoczne są bezpośrednio elementy związane w podatkiem odroczonym.

W rachunku zysków i strat odroczony podatek dochodowy nie jest widoczny, choć oczywiście występuje. Zmiany stanu aktywów i rezerwy z tytułu odroczonego podatku dochodowego ujmowane są per saldo z podatkiem bieżącym w pozycji ,podatek dochodowy”. Użytkownik tego sprawozdania musi mieć więc świadomość, że jeżeli jednostka gospodarcza rozlicza podatek odroczony, to jest to pozycja złożona i wyraża tzw. podatek w wymiarze księgowym (czy bilansowym), a zatem podatek w sensie fiskalnym skorygowany do postaci zgodnej z nadrzędnymi zasadami rachunkowości. Jeśli natomiast nie ustala podatku odroczonego, to pozycja ta wyraża wyłącznie podatek bieżący (czyli podatek w wymiarze fiskalnym). Biorąc pod uwagę użyteczność rachunku zysków i strat, wskazane byłoby rozbudowanie pozycji podatku dochodowego o informacje związane z podatkiem bieżącym i odroczonym osobno.

W zestawieniu zmian w kapitale własnym podatek odroczony jest właściwie niewidoczny i pozbawiony znaczenia informacyjnego. Prezentowany jest w ramach pozycji ,kapitał z aktualizacji wyceny” (podatek odroczony odnoszony na kapitał własny) oraz ,wynik z lat ubiegłych" (pozostały podatek odroczony).

W rachunku przepływów pieniężnych odroczony podatek dochodowy pojawia się tylko w metodzie pośredniej w ramach przepływów z działalności operacyjnej jako element korekt w pozycji 5 ,zmiana stanu rezerw” i 9 ,zmiana stanu rozliczeń międzyokresowych". Nie ma on jednak w tym sprawozdaniu większego znaczenia informacyjnego, ponieważ podawany jest jako jedna ze zmian rezerw czy rozliczeń międzyokresowych kosztów.

\section{Odroczony podatek dochodowy w sprawozdawczości finansowej wybranych jednostek gospodarczych}

W celu przedstawienia wpływu odroczonego podatku dochodowego na ustalanie zysku netto wybrano dwie jednostki gospodarcze z czołowej dziesiątki największych przedsiębiorstw w Polsce - PKN Orlen SA oraz Grupę Lotos SA. Obie jednostki należą do branży paliwowej. Okres, dla którego zaprezentowano dane, to 2016 i 2015 r. Dane pochodzą z raportów opublikowanych przez jednostki na swoich stronach internetowych. 


\section{PKN Orlen SA}

W raporcie rocznym za 2016 r. spółka prezentuje jednostkowe sprawozdanie dotyczące zysków lub strat i innych całkowitych dochodów, podając dane za 2016 i $2015 \mathrm{r}$. Wybrane pozycje tego sprawozdania przedstawiono w tabeli 3.

Tabela 3. Wybrane pozycje z jednostkowego sprawozdania dotyczącego zysków i strat PKN Orlen SA (dane w mln zł)

\begin{tabular}{|l|c|c|}
\hline \multicolumn{1}{|c|}{ Pozycja } & $2016 \mathrm{r}$. & $2015 \mathrm{r}$. \\
\hline Przychody ze sprzedaży & 53633 & 60466 \\
\hline Zysk brutto ze sprzedaży & 6969 & 4901 \\
\hline Zysk z działalności operacyjnej & 3869 & 1769 \\
\hline Zysk przed opodatkowaniem & 6069 & 1308 \\
\hline Podatek dochodowy: & $(705)$ & $(260)$ \\
- podatek dochodowy bieżący & $(489)$ & - \\
- podatek odroczony & $(216)$ & $(260)$ \\
\hline Zysk netto & 5364 & 1048 \\
\hline Inne całkowite dochody, które zostaną przeklasyfikowane na & & \\
zyski lub straty: & 43 & $(288)$ \\
\hline - podatek odroczony & 5177 & 2279 \\
\hline Całkowite dochody netto & & \\
\hline
\end{tabular}

Źródło: raport roczny PKN Orlen SA za 2016 r., http://www.orlen.pl/PL/RelacjeInwestorskie/ Strony/Sprawozdania-Finansowe-za-2016-rok.aspx (data dostępu: 10.08.2017).

Warto zwrócić uwagę, że spółka prezentuje wartość podatku odroczonego w sprawozdaniu, co znacznie podnosi jego walory informacyjne, tym bardziej że odroczony podatek dochodowy wykazywany w zysku netto stanowi istotny element obciążenia podatkowego. Za 2016 r. odroczony podatek dochodowy stanowi przeszło $30 \%$ łącznego obciążenia zysku netto podatkiem dochodowym, a za 2015 r. jest to $100 \%$, gdyż podatek w wymiarze fiskalnym nie wystąpił. Taka sytuacja nie pozostaje bez wpływu na ocenę zyskowności spółki. Najprostszy wskaźnik zysku za 2016 r. (relacja zysku netto do przychodów ze sprzedaży) na skutek rozliczenia podatku odroczonego spadł z $10,4 \%^{3}$ do $10 \%{ }^{4}$, czyli o 0,4 pkt proc., licząc w wartościach bezwzględnych (co daje spadek o ok. 3,85\%, porównując obie wartości). W 2015 r. wskaźnik ten spadł z 2,16\% do 1,73\%, co w wartości bezwzględnej oznacza spadek o 0,43 pkt proc., czyli podobnie jak w roku poprzednim (jednakże procentowo spadek wynosi już prawie $20 \%$,

${ }^{3}$ Zyskowność policzona bez uwzględniania odroczonego podatku dochodowego, a więc tak jakby jednostka zrezygnowała z ustalania i rozliczania tego podatku.

${ }^{4}$ Zyskowność policzona z uwzględnieniem odroczonego podatku dochodowego. 
porównując obie wartości). Wpływu podatku odroczonego nie można więc zbagatelizować i można zauważyć, że jego uwzględnianie zmienia wartość wskaźników analitycznych.

Wpływ odroczonego podatku dochodowego na obciążenie podatkowe zysku to zmiana stanu aktywów i rezerwy z tego tytułu. Jednostka w notach objaśniających podaje, jakie kategorie składają się na te zmiany, co zaprezentowano w tabeli 4.

Tabela 4. Aktywa z tytułu odroczonego podatku dochodowego PKN Orlen SA za 2016 i 2015 r. (w mln zł)

\begin{tabular}{|l|c|c|c|c|}
\hline \multicolumn{1}{|c|}{ Pozycja } & $\begin{array}{c}\text { Stan na } \\
31.12 .2016 \mathrm{r} .\end{array}$ & $\begin{array}{c}\text { Stan na } \\
31.12 .2015 \mathrm{r} .\end{array}$ & $\begin{array}{c}\text { Podatek } \\
\text { odroczony } \\
\text { ujęty w wyniku } \\
\text { finansowym }\end{array}$ & $\begin{array}{c}\text { Podatek } \\
\text { odroczony } \\
\text { ujęty w innych } \\
\text { całkowitych } \\
\text { dochodach }\end{array}$ \\
\hline $\begin{array}{l}\text { Odpisy aktualizujące } \\
\text { wartość aktywów }\end{array}$ & 51 & 62 & $(11)$ & - \\
\hline $\begin{array}{l}\text { Rezerwy i rozliczenia } \\
\text { międzyokresowe }\end{array}$ & 80 & 175 & $(95)$ & - \\
\hline $\begin{array}{l}\text { Niezrealizowane różnice } \\
\text { kursowe }\end{array}$ & 34 & 46 & $(12)$ & - \\
\hline $\begin{array}{l}\text { Strata podatkowa } \\
\text { Wycena instrumentów } \\
\text { finansowych }\end{array}$ & 73 & 35 & $(58)$ & 43 \\
\hline Pozostałe & 61 & 54 & 7 & - \\
\hline Razem & 350 & 481 & $(174)$ & 43 \\
\hline
\end{tabular}

Źródło: raport roczny PKN Orlen SA za 2016 r., http://www.orlen.pl/PL/RelacjeInwestorskie/ Strony/Sprawozdania-Finansowe-za-2016-rok.aspx (data dostępu: 10.08.2017).

Tabela 5. Rezerwa z tytułu odroczonego podatku dochodowego PKN Orlen SA za 2016 i 2015 r. (w mln zł)

\begin{tabular}{|l|c|c|c|c|}
\hline \multicolumn{1}{|c|}{ Pozycja } & $\begin{array}{c}\text { Stan na } \\
31.12 .2016 \mathrm{r} .\end{array}$ & $\begin{array}{c}\text { Stan na } \\
31.12 .2015 \mathrm{r.}\end{array}$ & $\begin{array}{c}\text { Podatek } \\
\text { odroczony } \\
\text { ujęty w wyniku } \\
\text { finansowym }\end{array}$ & $\begin{array}{c}\text { Podatek } \\
\text { odroczony } \\
\text { ujęty w innych } \\
\text { całkowitych } \\
\text { dochodach }\end{array}$ \\
\hline Ulga inwestycyjna & 29 & 33 & $(4)$ & - \\
\hline $\begin{array}{l}\text { Różnice przejściowe doty- } \\
\text { czące aktywów trwałych }\end{array}$ & 812 & 750 & 62 & - \\
\hline Pozostałe & 62 & 78 & $(16)$ & - \\
\hline Razem & 903 & 861 & 42 & - \\
\hline
\end{tabular}

Źródło: raport roczny PKN Orlen SA za 2016 r., http://www.orlen.pl/PL/RelacjeInwestorskie/ Strony/Sprawozdania-Finansowe-za-2016-rok.aspx (data dostępu: 10.08.2017). 
Jak wynika z tabeli 4, wartość aktywów z tytułu odroczonego podatku dochodowego spadła przy czym w wyniku finansowym został odnotowany spadek o $174 \mathrm{mln}$ zł (w kapitale własnym odnotowano wzrost wartości aktywów z tego tytułu o 43 mln zł). Spadek wartości aktywów z tytułu odroczonego podatku dochodowego oznacza wzrost obciążenia wyniku finansowego podatkiem dochodowym.

Rezerwa z tytułu odroczonego podatku dochodowego wzrosła w 2016 r. o $42 \mathrm{mln}$ zł, co oznacza, że również wzrosło obciążenie podatkowe wyniku finansowego podatkiem dochodowym. Zarówno zmiana stanu aktywów, jak i rezerwy z tytułu odroczonego podatku dochodowego wpływa na wzrost obciążenia wyniku finansowego podatkiem dochodowym i wynosi łącznie $216 \mathrm{mln}$ zł.

\section{Grupa Lotos SA}

Dane dotyczące odroczonego podatku dochodowego zostały przedstawione na podstawie jednostkowego raportu rocznego Grupy Lotos SA za 2016 r.

Tabela 6. Wybrane pozycje z jednostkowego sprawozdania dotyczącego całkowitych dochodów Grupy Lotos SA (dane w mln zł)

\begin{tabular}{|l|c|c|}
\hline \multicolumn{1}{|c|}{ Pozycja } & 2016 r. & 2015 r. \\
\hline Przychody ze sprzedaży & 18110016 & 20482298 \\
\hline Zysk na sprzedaży & 2531791 & $(19148443)$ \\
\hline Zysk operacyjny & 1487878 & 183757 \\
\hline Zysk przed opodatkowaniem & 1428116 & $(20713)$ \\
\hline Podatek dochodowy & $(267282)$ & $(16389)$ \\
\hline Zysk netto & 1160834 & $(37102)$ \\
\hline $\begin{array}{l}\text { Inne całkowite dochody oraz pozycje, które w przyszłości } \\
\text { mogą zostać przeklasyfikowane do wyniku: } \\
- \text { zabezpieczenia przepływów pieniężnych } \\
\text { - podatek dochodowy dotyczący zabezpieczenia przepływów } \\
\text { pieniężnych }\end{array}$ & 26254 & $(355973)$ \\
\hline Całkowite dochody netto & 1049558 & $(325410)$ \\
\hline
\end{tabular}

Źródło: raport roczny Grupy Lotos SA za 2016 r., http://inwestor.lotos.pl/193/raporty_i_dane/ raporty_roczne (data dostępu: 10.08.2017).

Analizując podane w tabeli 6 pozycje zaczerpnięte ze sprawozdania dotyczącego całkowitych dochodów, można zauważyć pewne różnice w stosunku do sprawozdania PKN Orlen SA. Poza nieznaczącymi różnicami w nazwach (zysk brutto ze sprzedaży - zysk na sprzedaży, zysk z działalności operacyjnej - zysk operacyjny) najważniejszą kwestią jest niepodanie przez Grupę Lotos SA podatku dochodowego w rozbiciu na podatek bieżący i odroczony. Wprawdzie w dalszej części raportu zostało to uzupełnione w osobnym punkcie, niemniej w samym 
sprawozdaniu nie ma takiego rozbicia. W osobnej nocie podano dane przedstawione w tabeli 7.

Tabela 7. Dane dotyczące podatku odroczonego Grupy Lotos SA za 2016 i 2015 r. (w tys. zł)

\begin{tabular}{|l|c|c|}
\hline \multicolumn{1}{|c|}{ Pozycja } & 2016 r. & 2015 r. \\
\hline Podatek bieżący & 43328 & 213 \\
\hline Podatek odroczony & 223954 & 16176 \\
\hline Razem podatek dochodowy wykazany w wyniku netto & 267282 & 16389 \\
\hline $\begin{array}{l}\text { Obciążenie podatkowe wykazane w innych całkowitych } \\
\text { dochodach netto, w tym z tytułu: } \\
\text { - zabezpieczeń przepływów pieniężnych } \\
\text { - zysków/strat aktuarialnych dotyczących świadczeń pracow- } \\
\text { niczych po okresie zatrudnienia }\end{array}$ & $\begin{array}{c}(26254) \\
152\end{array}$ & 11 \\
\hline
\end{tabular}

Źródło: raport roczny Grupy Lotos SA za 2016 r., http://inwestor.lotos.pl/193/raporty_i_dane/ raporty_roczne (data dostępu: 10.08.2017).

W tym wypadku problem wpływu podatku odroczonego na kształtowanie się zysku netto jest o wiele bardziej znaczący. Zarówno w 2016 r., jak i w 2015 r. wartość odroczonego podatku dochodowego przekracza wielokrotnie podatek bieżący. W 2016 r. udział podatku odroczonego w łącznym obciążeniu podatkowym wynosił prawie 84\%, w roku poprzednim był jeszcze większy i wynosił prawie $99 \%$. Wyeliminowanie podatku odroczonego z analizy sytuacji jednostki mogłoby w istotny sposób zmienić jej obraz. Wskaźnik zyskowności za 2016 r. policzony bez uwzględniania odroczonego podatku dochodowego wynosi 7,64\%, a z jego uwzględnieniem 6,41\%, co oznacza spadek wartości wskaźnika o 1,23 pkt proc. (procentowa zmiana to nieco ponad 16\%). Rok wcześniej ze względu na wykazanie strat wskaźniki przyjmują wartości ujemne, ale również wyeliminowanie podatku odroczonego z analizy zmienia istotnie wartość wskaźnika. Wskaźnik zyskowności policzony bez uwzględniania odroczonego podatku dochodowego wynosi $-0,102 \%$, natomiast $\mathrm{z}$ jego uwzględnieniem $-0,181 \%$. Spadek w wartościach bezwzględnych wynosi tylko 0,079 pkt proc., lecz zmiana procentowa to prawie $77,5 \%$. Różnice nie są bardzo duże, niemniej jednak są istotne i warto ten fakt uwzględniać.

5 Warto tu zwrócić uwagę, że oprócz sytuacji, gdy obie wartości wskaźnika zyskowności są dodatnie lub obie ujemne, możliwa jest sytuacja, gdy wartość wskaźnika zyskowności bez uwzględniania odroczonego podatku dochodowego jest dodatnia, a z jego uwzględnieniem ujemna lub wynosi zero. Sytuacje te ze względu na charakter wskaźnika zyskowności są bardzo rzadkie i wówczas należy poprzestać na obliczeniu tylko różnicy między pierwotnymi wskaźnikami. 
Jednostka w notach objaśniających do sprawozdania dotyczącego sytuacji finansowej podaje, jakie kategorie składają się na ujemne różnice przejściowe będące powodem powstania aktywów z tytułu odroczonego podatku dochodowego, co zaprezentowano w tabeli 8.

Tabela 8. Aktywa z tytułu odroczonego podatku dochodowego za 2016 i 2015 r. Grupy Lotos SA (w tys. zł)

\begin{tabular}{|l|c|c|c|}
\hline \multicolumn{1}{|c|}{ Pozycja } & $\begin{array}{c}\text { Stan na } \\
31.12 .2016 \mathrm{r} .\end{array}$ & $\begin{array}{c}\text { Stan na } \\
31.12 .2015 \mathrm{r} .\end{array}$ & $\begin{array}{c}\text { Podatek } \\
\text { odroczony ujęty } \\
\text { w sprawozdaniu } \\
\text { z całkowitych } \\
\text { dochodów }\end{array}$ \\
\hline Świadczenia pracownicze & 18757 & 20202 & $(1445)$ \\
\hline Odpisy aktualizujące wartość zapasów & 208 & 66989 & $(66781)$ \\
\hline Odpisy aktualizujące wartość należności & 9700 & 9647 & 53 \\
\hline $\begin{array}{l}\text { Odpisy aktualizujące wartość rzeczowych } \\
\text { aktywów trwałych }\end{array}$ & 4266 & 4266 & - \\
\hline $\begin{array}{l}\text { Ujemna wycena pochodnych instrumen- } \\
\text { tów finansowych }\end{array}$ & 13842 & 25592 & $(11750)$ \\
\hline Strata podatkowa rozliczana w czasie & 151664 & 379893 & $(228229)$ \\
\hline Zabezpieczenia przepływów pieniężnych & 190661 & 164407 & 26254 \\
\hline Pozostałe & 4800 & 4540 & 260 \\
\hline Razem & 393898 & 675536 & $(281638)$ \\
\hline
\end{tabular}

Źródło: raport roczny Grupy Lotos SA za 2016 r., http://inwestor.lotos.pl/193/raporty_i_dane/ raporty_roczne (data dostępu: 10.08.2017).

W tabeli 8, inaczej niż w przypadku PKN Orlen SA, nie dokonano rozróżnienia podatku odroczonego na ujmowany w wyniku finansowym i ujmowany w innych całkowitych dochodach. Rozróżnienie to wprowadzono w odrębnej tabeli, takie ujęcie sprawia jednak, że nie wiadomo, która z różnic wpływa na kapitały własne. Podobna sytuacja ma miejsce w przypadku różnic przejściowych dodatnich, które spowodowały utworzenie rezerwy z tytułu odroczonego podatku dochodowego ${ }^{6}$, co przedstawiono w tabeli 9.

Wykazanie obciążenia z tytułu podatku odroczonego w wyniku finansowym netto po uwzględnieniu zmiany stanu aktywów i rezerwy $\mathrm{z}$ tego tytułu powoduje, że ostatecznie otrzymujemy rezultat zmniejszenia tego obciążenia o 223954 tys. zł. Obciążenie to ujęte w innych całkowitych dochodach netto wynosi 26102 tys. zł, co razem daje spadek o 197852 tys. zł.

${ }^{6} \mathrm{~W}$ raporcie pozycja ta jest określana jako zobowiązania z tytułu odroczonego podatku dochodowego. 
Tabela 9. Rezerwa z tytułu odroczonego podatku dochodowego za 2016 i 2015 r. Grupy Lotos SA (w tys. zł)

\begin{tabular}{|l|c|c|c|}
\hline \multicolumn{1}{|c|}{ Pozycja } & $\begin{array}{c}\text { Stan na } \\
31.12 .2016 \mathrm{r} .\end{array}$ & $\begin{array}{c}\text { Stan na } \\
31.12 .2015 \mathrm{r} .\end{array}$ & $\begin{array}{c}\text { Podatek } \\
\text { odroczony ujęty } \\
\text { w sprawozdaniu } \\
\text { z całkowitych } \\
\text { dochodów }\end{array}$ \\
\hline $\begin{array}{l}\text { Różnica między wartością podatkową } \\
\text { i księgową rzeczowych aktywów trwałych } \\
\text { i aktywów niematerialnych }\end{array}$ & 361655 & 421297 & $(59642)$ \\
\hline $\begin{array}{l}\text { Dodatnia wycena pochodnych instrumen- } \\
\text { tów finansowych }\end{array}$ & 11847 & 37732 & $(25885)$ \\
\hline Pozostałe & 1900 & 159 & 1741 \\
\hline Razem & 375402 & 459188 & $(83786)$ \\
\hline
\end{tabular}

Źródło: raport roczny Grupy Lotos SA za 2016 r., http://inwestor.lotos.pl/193/raporty_i_dane/ raporty_roczne (data dostępu: 10.08.2017).

Porównując obie jednostki w zakresie podatku odroczonego, można dostrzec wiele podobieństw, co jest korzystne z punktu widzenia analitycznego. Obie jednostki wykazują znacznie więcej różnic przejściowych ujemnych niż dodatnich, prezentują je jednak z różnym stopniem szczegółowości. Chodzi tu przede wszystkim o odpisy aktualizujące wartość aktywów, które w przypadku PKN Orlen SA zostały podane jako jedna pozycja, podczas gdy w przypadku Grupy Lotos SA zostały uszczegółowione dla trzech kategorii aktywów. Różnice dodatnie w obu jednostkach dotyczą różnic pomiędzy wartością podatkową i księgową rzeczowych aktywów trwałych oraz w przypadku PKN Orlen SA ulgi inwestycyjnej, a w Grupie Lotos SA dodatniej wyceny instrumentów pochodnych. Pozostałe różnice zostały określone w obu jednostkach jako „pozostałe”. Istotną kwestią jest sposób prezentacji podatku odroczonego w rachunku zysków i strat (w sprawozdaniu dotyczącym całkowitych dochodów). Wydaje się, że sposób prezentacji, jaki przyjęto w PKN Orlen SA, czyli podanie wartości podatku dochodowego w rozbiciu na podatek bieżący i podatek odroczony, powinien być modelem obowiązującym.

Do zaprezentowania wpływu podatku odroczonego na kształtowanie się wyniku finansowego netto wybrano losowo dwie jednostki z pierwszej dziesiątki największych przedsiębiorstw w Polsce. Jedynym kryterium wziętym pod uwagę była branża, aby uniknąć ewentualnych różnic wynikających z jej specyfiki. Wyniki tej pobieżnej analizy wydają się co najmniej zastanawiające, a wpływ podatku odroczonego na kształtowanie się wyniku finansowego netto jest zaskakująco wysoki. Wskazane jest zatem przeprowadzenie dalszych badań w tym zakresie na zdecydowanie większej próbie, np. 100 lub nawet 500 największych 
polskich przedsiębiorstw, tak aby w wiarygodny sposób ten wpływ określić. Wydaje się, że warto podjąć tego typu badania, pozwoliłoby to bowiem poszerzyć analizę sytuacji finansowej jednostek gospodarczych. Badania takie prowadzone np. przez T. Maślankę (2015) w zakresie płynności czy stopnia zadłużenia polskich przedsiębiorstw mogłyby zostać wzbogacone o ten aspekt.

\section{Podsumowanie}

Odroczony podatek dochodowy to kategoria istniejąca wyłącznie w rachunkowości. Jego głównym zadaniem jest skorygowanie wielkość podatku wyliczonego zgodnie z przepisami podatkowymi do wysokości zgodnej z nadrzędnymi zasadami rachunkowości. Jak zaprezentowano w artykule, może on istotnie wpływać na wielkość obciążenia podatkowego, zmieniając wysokość zysku netto. Prowadzić to może do zmiany obrazu jednostki w przeprowadzanej analizie, gdyż zysk netto jest najczęściej wykorzystywaną kategorią obrazującą rezultaty działalności. Ponieważ wnioski sformułowane zostały tylko na podstawie dwóch przypadków, wskazane jest poszerzenie analizy w celu uogólnienia tych wniosków. Zwiększy to możliwości badania sytuacji finansowej jednostek gospodarczych.

\section{Literatura}

Hołda A. (2013), MSR/MSSF w polskiej praktyce gospodarczej, Wydawnictwo C.H. Beck, Warszawa.

Krajowy Standard Rachunkowości nr 2, „Podatek dochodowy”, Dz. Urz. Ministra Finansów z 28.07.2010, nr 7, poz. 31.

Maślanka T. (2014), Płynność finansowa a rentowność przedsiębiorstw (w:) Rentowność przedsiębiorstw w Polsce, red. Z. Dresler, Wydawnictwo Uniwersytetu Ekonomicznego w Krakowie, Kraków.

Maślanka T. (2015), Analiza płynności sektora przedsiębiorstw w Polsce w latach kryzysu (w:) Z. Dresler, J. Wyrobek, Kondycja ekonomiczna przedsiębiorstw w Polsce w latach kryzysu, Szkoła Wyższa im. Bogdana Jańskiego, Kraków.

Międzynarodowy Standard Rachunkowości nr 12, Dz. Urz. UE L. 320/53 z 29.11.2008, ze zm.

Olchowicz I. (2009), Rachunkowość podatkowa, Difin, Warszawa.

Olchowicz I., Tłaczała A. (2008), Sprawozdawczość finansowa według krajowych i międzynarodowych standardów, Difin, Warszawa.

Rachunkowość finansowa i podatkowa (2005), red. T. Cebrowska, Wydawnictwo Naukowe PWN, Warszawa.

Ustawa z dnia 26 lipca 1991 r. o podatku dochodowym od osób fizycznych, t.j., Dz.U. 2016, poz. 2032, ze zm.

Ustawa z dnia 15 lutego 1992 r. o podatku dochodowym od osób prawnych, t.j., Dz.U. 2016, poz. 1888 , ze zm. 
Ustawa z dnia 29 września 1994 r. o rachunkowości, t.j., Dz.U. 2016, poz. 1047.

Ustawa z dnia 9 listopada 2000 r. o zmiania ustawy o rachunkowości, t.j., Dz.U. nr 113, poz. 1186.

Ustawa z dnia 23 lipca 2015 r. o zmianie ustawy o rachunkowości oraz niektórych innych ustaw, Dz.U. poz. 1333.

Walińska E. (1997), Rachunkowość finansowa w świetle podatku dochodowego, FRRwP, Warszawa.

Walińska E. (2003), Rachunkowość podatków odroczonych, FRRwP, Warszawa.

\section{The Effect of Deferred Income Tax on the Profit of the Enterprise}

(Abstract)

The article examines the discrepancy between accounting law and tax law regarding the determination of financial results (income) and the presentation of the role of deferred income tax in offsetting tax burdens so as to comply with superior accounting principles. The article analyses profit and loss accounts published by randomly selected entities from the list of the largest enterprises in Poland in 2016. It examines the relations that would appear if the entity determined and did not determine the deferred income tax as well as how the profit indicator in both situations would be shaped. Based on this analysis, a preliminary application on the essential impact of deferred income tax on the development of net profit was formulated. This conclusion, however, should be verified on a much larger research sample.

Keywords: deferred income tax, balance sheet liability method, financial reporting, profitability. 